With all these preliminaries in mind, the second part of this work concentrates around the study of the theme of duality, as extension of the myth of Narcisus, in a selection of works considered by the author to be representative of Victorian literature. The motif of duality (alter ego) is affirmed over other motifs in the literary argument of Narcisus. The author explores the theme of duality in Mary Shelley's Frankenstein; Emily Brontë's Wuthering Heights; Charlotte Brontë's Jane Eyre; Lewis Carroll's Alice Through the Looking-Glass; R.L. Stevenson's Dr. Jekyll and Mr. Hyde; Oscar Wilde's The Picture of Dorian Gray; Abraham Stoker's Dracula; H.G. Wells's The Invisible Man and James Barrie's Peter Pan. The final conclusion is that British literature of the second half of the nineteenth century is the prelude to psychoanalysis in so far as psychoanalysis is going to systematize the human preoccupation for "its other" (the duality analysed in the works selected) in what will become the subconscious. Finally, the reader will find an exhaustive bibliographical section organized in parts according to the different texts under consideration and offering a plurality of readings on these same texts.

Ana Moya

Rodríguez Álvarez, Alicia. Documentos notariales vernáculos del condado de Durham (siglo XV): Estudio y edición. Córdoba: Servicio de Publicaciones de la Universidad de Córdoba y Servicio de Publicaciones de la Universidad de Las Palmas de Gran Canaria, 1997, 253 pp.

It is only within the last decades that there is a renewed interest in performing translations and studies of mediaeval English texts, others than literary. This interest could be a response to a great concern for the generally neglected study of the history of English from other non-literary perspectives that may account for specific phenomena not yet discussed in detail by specialists. In this context, the work Documentos notariales vernáculos del condado de Durham (siglo XV): Estudio $y$ edición (henceforth Documentos notariales) emerges bringing new information about late mediaeval English legal text language and structure.

Rodríguez's Documentos notariales is divided into four main parts covering a great deal of what has been said about mediaeval English legal language and texts: Los documentos, Los escribanos, Los textos, and Edición. The book also comprises an Introducción, Glosario de términos y expresiones legales, Glosario de medidas de superficie, tipos de terrenos y divisiones administrativas, Índice de nombres propios, Índice de topónimos, Mapa del condado de Durham, Índice de comienzos de oraciones, Bibliografía and Figuras.

In part one Los documentos, Rodríguez Álvarez describes not only the physical side of the documents, but also their contents, what serves as main division to her material. The total amounts to the impressive number of 57, some of them not found in the Linguistic Atlas of Late Mediaeval English (1986) and whose data are included in this book for the first time. In this part, the reader is also given some information concerning 
the English legal system of the time, and, more specifically, the legal instruments edited in this work in order to familiarise him/her with their contents. In addition, details regarding the seals attached to the documents are also presented. The author offers under Figures drawings intended for illustration of this part.

The importance of literacy and education connects with the issue of bureaucratic documents, and the need to preserve possessions in written form what, in the case of the documents studied in this book, was generally a task which the population normally required from official scribes and from those monks who had training in a scriptorium. In the second part, the author analyses the question of literacy and she provides a description of those mediaeval men in charge of producing written legal documents in the county of Durham, hence outlining the academic profiles of the scribes, clergy or layman, perfectly aware of the power of the written word to secure their possessions. The transition to the Englishing of legal documents is explained, in this second part, in terms of unsufficient training in Latin. In this sense, those who did not attempt higher academic courses after school had a very elementary knowledge of that classical language.

In part number three, a study of the textual analysis of the legal documents presented here along with the language that characterises this type of writing is performed. Firstly, the author outlines and describes the diplomatic composition of texts. Secondly, recurrent grammatical structures and formulae in the texts are analysed. Likewise, Rodríguez Álvarez suggests the association of certain formulae and expressions with particular sections within the legal document. Finally, the author concentrates on the punctuation displayed to mark division. On many occassions, as she explains, this sentence division is not only a question of the unreliable mediaeval punctuation signs, but of certain expressions and clichés that might warn readers of the beginning of another sentence unit.

The study of punctuation in mediaeval manuscripts is one of the main achievements of Rodríguez Álvarez who proves the existence of a sort of regularity in the use of punctuation conventions against the view of some critics for whom the role of punctuation in mediaeval texts "parecía inexistente" (p. 134).

In part four, the editorial method for the transcription is presented, and then the edition of hitherto unpublished texts are given. Each text is preceded by specific data related to that document: place and document signature, date, type of document and the contents, measure, ink colour, condition of the document, and further information related to the document which differs from one text to another.

In order to help the reader to understand the texts, a number of glossaries which I have mentioned above are included at the end of the book together with a map of the county of Durham where all the places mentioned in the documents are indicated. The entries in the glossaries are followed by the number of the documents where they are contained in brackets, and, in the case of the Glosario de terminos y expresiones legales, the number of the line is also offered.

In conclusion, there is no doubt that Rodríguez Álvarez offers a serious work and rich in detail, and I have no reservations to regard the book as highly commendable.Yet, it is still to be done a comparison of the language these texts display with London 
Chancery legal documents in order to see the degree of standardisation they present. All in all, Documentos notariales reads very well, and is absolutely reader-friendly. It stands as an important contribution for historical studies of English, and the texts presented here may be used for further diachronic studies of the English language.

Francisco Alonso Almeida

\section{Paul Tench (1996). The Intonation Systems of English. New York: Cassell.160 pp.}

It is only within the last 30 years that the study of suprasegmental phenomena has begun to flourish. This may be due to technological advances that have helped researchers in the storing and analysis of intonational data. In this context, the importance of Tench's book relies on the fact that it emerges at a time when there is a great need for a comprehensive study that surveys the most relevant descriptions of intonation.

Another advantage of Tench's book is that, throughout its six chapters, it instils the reader with the idea that the function and description of intonation are a matter for linguistic analysis, since intonation can be described in terms of a set of contrasts. This approach departs significantly from the view widely held among students and some scholars that intonation has a blurred and shapeless identity.

The language used by Tench is largely straightforward, and generally accessible to the novice reader. The book reads very well and may be described as user-friendly.

I begin here by describing the book's layout, and then go on to comment on specific aspects of the text, in an attempt to assess the extent to which the book succeeds in achieving the goal (given below) that the author sets out in the introduction:

This book is intended to introduce to language students and teachers a description of English intonation that will take into account the actual nature of intonation and its functions in spoken language (p.2).

The Intonation Systems of English (henceforth, TISE) consists of a Preface, an Acknowledgement List, followed by six chapters, a Reference Section, and an Index in a total of 160 pages. Chapter 1 offers an introduction to the general field of intonation. Chapters 2, 3 and 4 present the three major components, respectively, of the system put forward by Halliday in his 1967 book titled Intonation and Grammar in British English, which is published by Mouton (The Hague): tonality, tonicity and tone. In chapter 5 , Tench analyses the nature of tone in greater detail. Chapter 6 closes the discussion firstly by presenting an outline of the main models of communication included in the literature, and then by showing how intonation participates in the process of communication. Excepting chapter 6, all chapters end with a list of short notes. There is a short practical exercise towards the end of chapter 3, and several exercises are scattered throughout the text. Otherwise, the book lacks any kind of formal exercises. 